\title{
Effects of columbite/tantalite (COLTAN) mining activities on water quality in Edege- Mbeki mining district of Nasarawa state, North Central Nigeria
}

\author{
Mohammed Engha Isah ${ }^{1 *}$ (D, Nuhu Abdulkadir Abdulmumin², Paul D. Elaoyi ${ }^{2}$ and Ephraim Audu ${ }^{3}$
}

\begin{abstract}
Background: The release of environmental pollutants such as heavy metals due to mining activities has received worldwide condemnation. Therefore, understanding the contamination of both surface and groundwater in EdegeMbeki mining district is very important for the health and wellbeing of its people. Hence, the purpose of this study was to determine the physicochemical parameters of water samples and the level of heavy metals in Edege-Mbeki Columbite/Tantalite (COLTAN) mining site, North Central Nigeria.
\end{abstract}

Results: A total of 15 water samples were collected and analyzed in triplicate. The concentrations of five heavy metals ( $\mathrm{Ni}, \mathrm{Mn}, \mathrm{Pb}, \mathrm{Cd}$, and $\mathrm{Fe}$ ) in surface and groundwater samples were measured using atomic absorption spectrophotometer (AA-6800 Shimadzu). The physicochemical properties of the water samples were also examined. The results of the water quality assessments show that the water samples were contaminated with alarming levels of $\mathrm{Pb}, \mathrm{Cd}$ and $\mathrm{Ni}$. Mean concentrations were $\mathrm{Ni}(0.008 \mathrm{mg} / \mathrm{L}), \mathrm{Mn}(0.087 \mathrm{mg} / \mathrm{L}), \mathrm{Pb}(0.324 \mathrm{mg} / \mathrm{L}), \mathrm{Cd}(0.029 \mathrm{mg} / \mathrm{L})$, and Fe $(0.839 \mathrm{mg} / \mathrm{L})$ in Edege-Mbeki groundwater, while the surface water (mining ponds) had $\mathrm{Ni}(0.102 \mathrm{mg} / \mathrm{L}), \mathrm{Mn}$ $(0.099 \mathrm{mg} / \mathrm{L}), \mathrm{Pb}(0.358 \mathrm{mg} / \mathrm{L}), \mathrm{Cd}(0.025 \mathrm{mg} / \mathrm{L})$, and Fe $(6.99 \mathrm{mg} / \mathrm{L})$. The groundwater samples in Mararaban-Edege which served as the control site had mean concentration levels of $\mathrm{Ni}(0.032 \mathrm{mg} / \mathrm{L}), \mathrm{Mn}(0.096 \mathrm{mg} / \mathrm{L}), \mathrm{Pb}(0.122 \mathrm{mg} /$ $\mathrm{L}), \mathrm{Cd}(0.039 \mathrm{mg} / \mathrm{L})$, and $\mathrm{Fe}(0.608 \mathrm{mg} / \mathrm{L})$. The range of $\mathrm{pH}$ was found to be from $5.6 \pm 0.02$ to $6.5 \pm 0.12$, turbidity was between $39.27 \pm 0.29$ and $2271 \pm 0.00 \mathrm{NTU}$, and conductivity ranged from $39.27 \pm 0.29$ to $757.33 \pm 5.69 \mu \mathrm{S} / \mathrm{cm}$, TDS from $25.0 \pm 2.3$ to $450.67 \pm 6.03 \mathrm{mg} / \mathrm{L}$ while dissolved oxygen (DO) values from $3.1 \pm 0.3$ to $3.5 \pm 0.3 \mathrm{mg} / \mathrm{L}$.

Conclusion: This study confirmed that surface and ground water samples in Edege-Mbeki and Mararaban-Edege are not fit for human consumption and other domestic use. Hence, government and community leaders must provide alternative means of water for the people of these communities.

Keywords: Heavy metals, Edege-Mbeki, Mararaban-Edege, Pollution, Toxic, Physiochemical

\section{Background}

The pollution of water sources by heavy metals has received attention and widespread condemnation from environmentalists owing to the toxicity, abundance, persistence, and biomagnifications of heavy metals in the environment and their long-term accumulation in marine organisms (Wei et al. 2018). Heavy metals in the

\footnotetext{
* Correspondence: mohdisah048@gmail.com

${ }^{1}$ Renaissance Environmental Limited, No 12 Cape Town Street Wuse District

Zone 4, Abuja, Nigeria

Full list of author information is available at the end of the article
}

environment could originate from either natural or anthropogenic sources (Masindi and Muedi 2018). However, anthropogenic activities such as mining are known to release a significant amount of toxic metals into the environment (EPA 2007). Research has shown that mining is the most critical contributor to heavy metal pollution in river basins. Apart from the pollution of water bodies by heavy metals, mining activities bring about the destruction of the natural ecosystem through the alteration of soil vegetative cover and the fauna beneath (Ologundudu 2019). Therefore, mining poses a great 
toxicological danger for the surrounding ecosystem and the human population (Franco-Hernández et al. 2010). From the foregoing, therefore, it is very imperative to understand the concentration, distribution, and sources of heavy metals in the environment. This will serve as a scientific point of reference for the protection of water resources, the control of water pollution and the remediation of polluted sources (Wei et al. 2018).

The mining of columbite/tantalite (COLTAN) has a negative effect on the different spheres of the environment notably; hydrosphere, lithosphere, and the atmosphere (Eisler 2004). Just like gold mining, COLTAN extraction involves the breaking of crystallographic bond in the mineral ore to get the products in the pure form. By so doing, a large quantity of waste is generated and subsequently released into the environment (Ologundudu 2019).

Acid mine drainage is one of the major sources of toxic metals that is associated with high concentrations of iron, mercury, arsenic, and antimony, thus contaminating both ground and surface water (Corkhill and Vaughan 2009). The use of fossil fuels for energy generation used in large scale mining operations also releases huge amounts of toxic metals into the atmosphere. A series of reactions in the atmosphere ensures that the toxic metals end up in the water body, hence, contaminating it (Adejumoke et al. 2018). Furthermore, seasonal variability in precipitation and temperature has a significant impact on the concentration of toxic metals and the effects on wildlife (Said et al. 2012).

Edege-Mbeki plays an essential role in Nasarawa Local Government Area in terms of revenue generation and agricultural activities. The Nigerian government's drive to diversify the economy to reduce its dependence on oil revenue has seen an influx of both registered companies as well as artisanal miners into the old mining town. Over 60 years of unsustainable mineral exploration and mining activity have severely damaged the fragile local ecological environment and compromised water quality. Additionally, most of the mines are located near Paddock (the biggest mining pond in the mining district) and Odemu, two of the vital sources of water. Hence, the quality of water has deteriorated. These areas have increasingly brought about conflict between locals and the miners and drawn the attention of local and state governments. Suffice it to say that little attention has been paid to the deterioration of the water quality in response to human activities such as mining.

In order to evaluate the damages that COLTAN mining activities exert on the environment, especially in areas where old methods of mining are still practiced, this present study aimed to investigate the contents of $\mathrm{Ni}, \mathrm{Mn}, \mathrm{Pb}, \mathrm{Cd}$, and $\mathrm{Fe}$ in ground and surface water in the mining district of Edege-Mbeki and to determine how the physicochemical parameters affect heavy metals' concentration. The choice of these heavy metals is premised on their potentially toxic nature and their adverse health effects above a threshold level (Khan and Bhat 2011). The results obtained can be applied to improve water management efficiency.

\section{Study area}

Edege-Mbeki is located in Nasarawa local government area of Nasarawa state, North Central Nigeria, at latitude $08^{\circ} 19^{\prime} 30^{\prime \prime} \mathrm{N}$ and longitude $70^{\circ} 50^{\prime} 80^{\prime \prime} \mathrm{E}$ (Fig. 1) with an area of about $400 \mathrm{~km}^{2}$. The area falls within the tropical guinea savannah with a mean annual rainfall of $1000-1500 \mathrm{~mm}$ and a mean temperature of $25.60{ }^{\circ} \mathrm{C}$ (Akintola 1986).

Edege-Mbeki mining district (Fig. 2) is geologically underlain by the cretaceous sedimentary rocks and the Jurassic younger granite of the middle Benue trough. The Benue trough is a rift basin that extends for about $800 \mathrm{~km}$ in length and $150 \mathrm{~km}$ in width, with approximately $6000 \mathrm{~m}$ of cretaceous tertiary sediments (Okegye and Gajere 2015). In the study area, the main anthropogenic activities consist of agriculture, mining, and grazing. However, agricultural activity in this area has greatly dwindled due to mining and insecurity problems.

\section{Materials and methods}

\section{Water sample collection and pre-treatment}

To assess the water quality and the concentration of heavy metals in the study area, a total of 15 water samples were collected from mining ponds and hand-dug wells in April 2017. The collection and preservation of all water samples were carried out according to the methods of APHA (2005). Well-labeled and preserved polyethylene sampling bottles $\left(2 \mathrm{dm}^{3}\right)$ previously cleaned by washing in detergent, rinsed with tap water, and later soaked in $10 \% \mathrm{HNO}_{3}$ for $24 \mathrm{~h}$ and finally rinsed with distilled water before they were used for sampling. At each sampling point, the bottles were rinsed three times with the water before the collection of a $15-\mathrm{ml}$ water sample. Figure 2 shows all the sampling sites and the distribution of mines. Five water samples were collected in the mining ponds around the mines; one of which was collected from tailings pond, and five hand-dug well water samples were collected from Edege-Mbeki town. Furthermore, five hand-dug well water samples were also collected at Mararaban-Edege (control site). At the time of sampling, there was no control for surface water because all the streams in the area had dried up.

All the water samples collected were filtered into polyethylene sampling bottles that were prewashed with de-ionized water. During the sampling times, parameters such as $\mathrm{pH}$, electrical conductivity, temperature, and total dissolved solids were measured on-site using a 


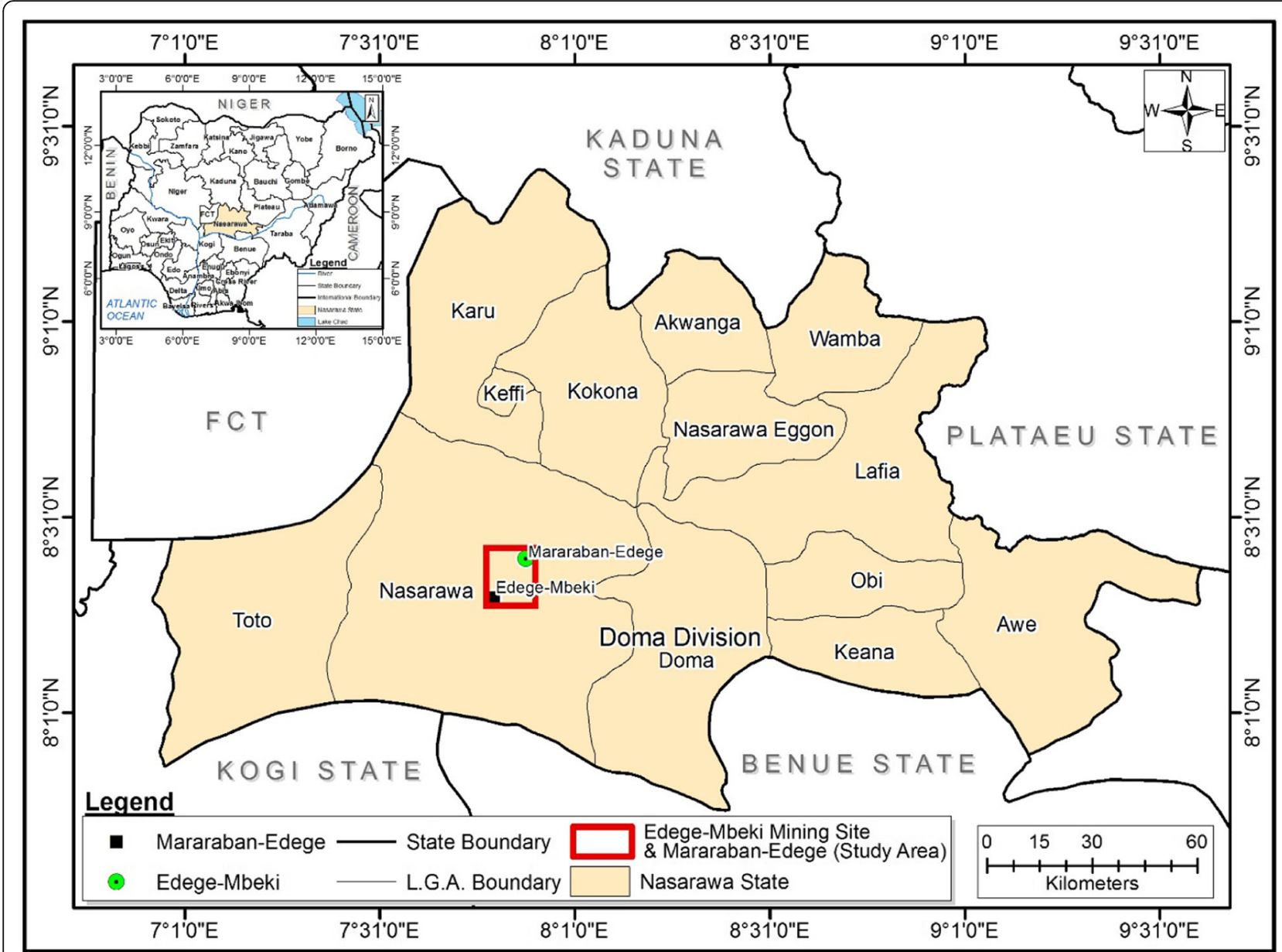

Fig. 1 Map of Nasarawa state and the study area

portable Jenway $\mathrm{pH} /$ conductivity meter (Jenway 430), and turbidity was measured using a portable Hanna digital turbidity meter while the dissolved oxygen level was measured using a Biocotek portable DO analyzer. The $\mathrm{pH}$ meter was calibrated with $\mathrm{pH} 4$ and 7 standards. The collected water samples were preserved by acidifying with concentrated $\mathrm{HNO}_{3}$ to keep the metal ions in the dissolved state and slow down microbial activities (Boamponsem et al. 2010) and then stored in the ice chest at $4{ }^{\circ} \mathrm{C}$ and shipped to the laboratory for heavy metal analysis.

\section{Digestion of water samples for heavy metal analysis}

Exactly $5 \mathrm{ml}$ of water samples were digested by the addition of exactly $10 \mathrm{ml}$ of concentrated nitric acid and $10 \mathrm{ml}$ of hydrogen peroxide. This was heated on a hot plate to about half the original volume. The flask was allowed to cool, its contents were filtered into a $25-\mathrm{ml}$ standard volumetric flask and made up to the mark with distilled water according to Popoola et al. (2011). The digest was then filtered into $25-\mathrm{ml}$ standard flask, and cooled and diluted to mark. To rule out experimental bias or some random error, triplicate digestion of each sample was carried out and a portion of the solution was used for heavy metal determination. The analysis was conducted using a flame atomic absorption spectrophotometer (model AA240FS).

\section{Quality assurance and quality control}

To ensure that the results were authentic and correct, strict quality assurance and control protocols were rigorously adhered to. All the chemicals and reagents used were of analytical grade. All polyethylene sampling bottles and glassware used in the laboratory were cleaned by washing with detergent, rinsed in tap water, later soaked in $10 \% \mathrm{HNO}_{3}$ for $24 \mathrm{~h}$, and then finally rinsed with distilled water before use for sampling (APHA 2005). 


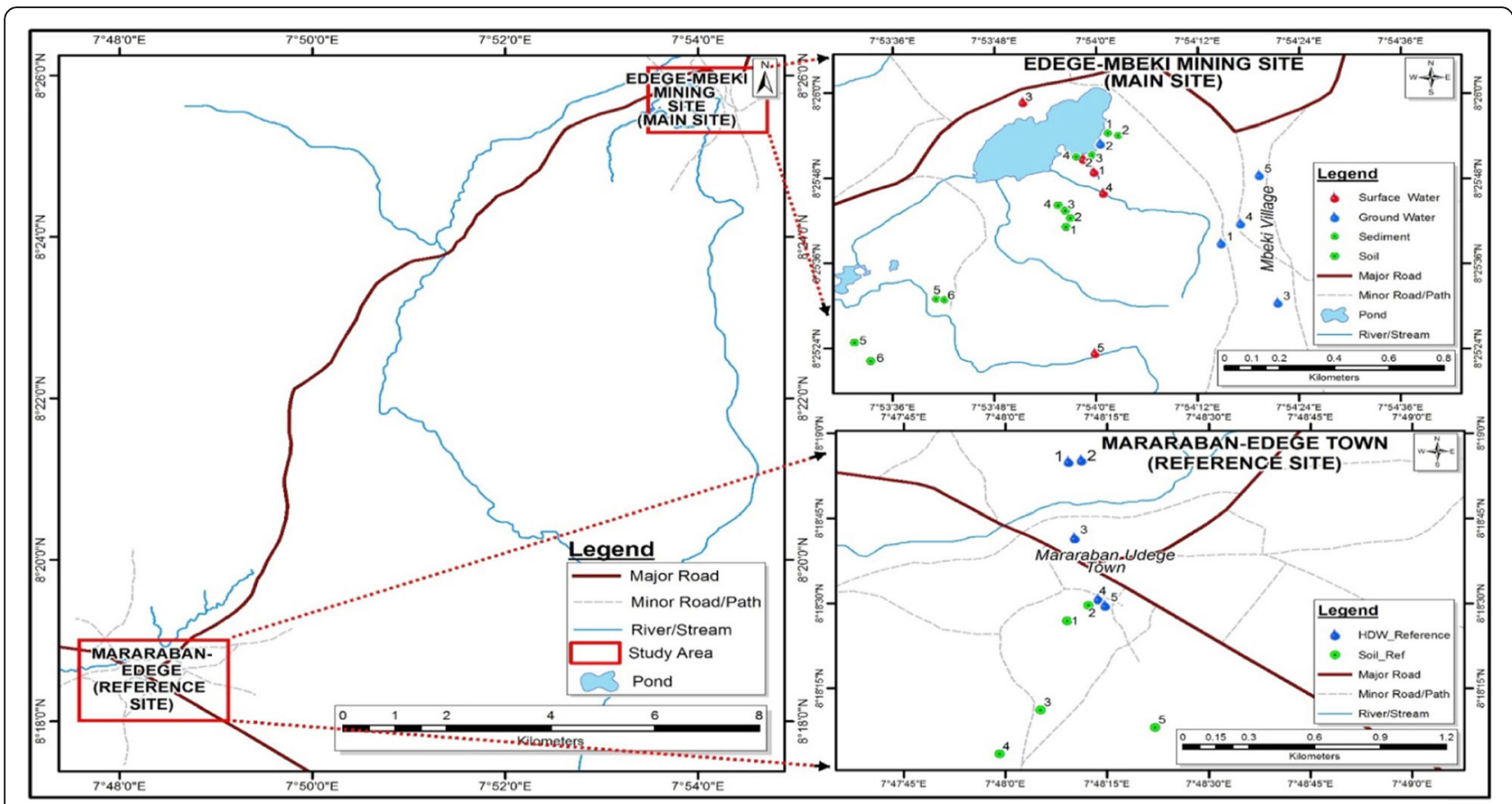

Fig. 2 The map of Edege-Mbeki showing the different sampling points

\section{Geostatistical analysis}

- The contamination factor $(\mathrm{CF})$ is obtained using the following equation:

\section{Contamination factor $(\mathrm{CF})$$$
=\frac{\text { Concentration of metal in sample }}{\text { Concentration of metal in background }}
$$

which was used by Boamponsem et al. (2010). In this research work, the WHO (2004) guidelines for drinking water quality were selected as the background level for the calculation of the contamination factor of the water samples.

\section{Modified degree of contamination $\left(m C_{d}\right)$}

The excessive value of monitored heavy metals in water samples was assessed using a modified and generalized form of Hakanson equation (Ata et al. 2009). This equation is given as follows:

$$
\operatorname{mCd} \frac{\sum_{i=1}^{i=n} C^{i} f}{n}
$$

where $n=$ number of analyzed elements, $i=i$ th element or pollutant, and $\mathrm{CF}=$ contamination factor. Table 1 gives a gradation of the classification and description of the mCd according to Abrahim and Parker (2008).

\section{The pollution load index (PLI) of heavy metals}

This index has been used for pollution assessment of heavy metals in the water samples within the area of study (Bhupander et al. 2011). The pollution load index for each site was calculated using the following relation:

$$
P L I=\sqrt[n]{C F 1 X C F 2 X C F 3 X \ldots X C F n}
$$

where $\mathrm{CF}$ is the contamination factor of each metal that will be examined, and $n$ equals the number of contamination factor.

A PLI value $>1$ indicates pollution whereas PLI value $<1$ indicates no pollution (Ong et al. 2012).

Table 1 Modified degree of contamination gradation

\begin{tabular}{ll}
\hline $\begin{array}{l}\text { Modified degree of contamination } \\
(\mathrm{mCd})\end{array}$ & $\begin{array}{l}\text { According to [Abrahim and Parker } \\
\text { 2008] }\end{array}$ \\
\hline $\mathrm{mCd}<1.5$ & $\begin{array}{l}\text { Nil to very low degree of } \\
\text { contamination }\end{array}$ \\
$1.5<\mathrm{mCd}<2$ & $\begin{array}{l}\text { Low degree of contamination } \\
\text { Moderate degree of } \\
\text { contamination }\end{array}$ \\
$4<\mathrm{mCd}<4$ & High degree of contamination \\
$8<\mathrm{mCd}<8$ & $\begin{array}{l}\text { Very high degree of } \\
\text { contamination }\end{array}$ \\
$16<\mathrm{mCd}>32$ & $\begin{array}{l}\text { Ultra-high degree of } \\
\text { contamination }\end{array}$ \\
$\mathrm{mCd}<32$ & $\begin{array}{l}\text { Extremely high degree of } \\
\text { contamination }\end{array}$ \\
\hline
\end{tabular}




\section{Enrichment factor (EF) of heavy metals}

An enrichment factor is a parameter that is used to evaluate natural or anthropogenic sources of heavy metal content in the soil and water (Ata et al. 2009). This index was used to distinguish between natural and anthropogenic sources. To calculate the enrichment factors for the entire element, iron ( $\mathrm{Fe}$ ) will be used as a reference element. Reference elements are mostly conservative ones, such as the most commonly used elements which include Fe, Sc, and Ti (Hernadez et al. 2003; Ata et al. 2009).

$$
E F=\frac{\left[\left(\frac{C n}{C F e}\right)\right] \text { Sample }}{\left[\left(\frac{C n}{C F e}\right)\right] \text { Shale }}
$$

where $(\mathrm{Cn} / \mathrm{Cfe})$ sample is the ratio of the concentration of the element of concern $(\mathrm{Cn})$ to that of $\mathrm{Fe}$ in the sediment sample and $(\mathrm{Cn} / \mathrm{Cfe})$ shale has the same ratio with an unpolluted reference sample.

\section{Results}

The results of the study carried out on both surface and groundwater samples are presented below (Table 2). Triplicate determinations were carried out simultaneously for each sample and the results were recorded as average.

\section{Discussion}

Water physicochemical properties and quality assessment $\mathrm{pH}$

According to Fakayode (2005), the $\mathrm{pH}$ of a water body determines the quality because it affects the solubility and toxicity of metals. The $\mathrm{pH}$ of both ground and surface water in the study area is slightly acidic. During the present investigation, the mean $\mathrm{pH}$ of the water samples (well) was observed to be less than the WHO (2004) permissible range of 6.5 and 9.2 units. However, the $\mathrm{pH}$ level of surface water $(6.57 \pm 0.21)$ was within the WHO permissible range. It is important to note that the groundwater sample in the control area is more acidic than the study area. This may be attributed to the composition of rocks and sediments. Furthermore, the high acidity may be linked to the high concentration of $\mathrm{CO}_{2}$ due to more human activities in the control area
(Osinbajo 2012). Acidic water has been shown to lower the $\mathrm{pH}$ of water, hence, increasing the concentration of heavy metals such as lead, copper, and zinc (SON 2007).

\section{Electrical conductivity}

Electrical conductivity (EC) measures the ability of water to conduct electricity, which is related to the amount of dissolved minerals in the water without an indication of which element is present or absent. A high value of EC is an indication of the presence of sodium, potassium, chloride, or sulfate contaminants (Orebiyi et al. 2010). EC conductivity is a good way to measure the total dissolved ions as it has a direct relationship with the total amount of solids in the water samples. This then means that a high number of dissolved ions in water translate to a greater number of ions in water (Adewoye et al. 2013). Analysis of the results of this research shows that the EC of all the water sampled were below the WHO (2004) permissible limit of $1000 \mu \mathrm{S} / \mathrm{cm}$ (Table 2).

\section{Total dissolved solid (TDS)}

Total dissolved solids refer to the inorganic and small amounts of organic matter present in solution in water (WHO 2006). There are no known possible health effects associated with the ingestion of drinking waters with high total dissolved solids. Rather, the result of an early epidemiological study shows that low concentrations of TDS in drinking water have beneficial effect. However, the presence of high TDS may be unacceptable to consumers due to the taste and scaling of pipes, boilers, heaters, and household appliances (WHO 2006). All the water samples analyzed in the study area were found to be below the WHO (2004) permissible limits of $500 \mathrm{mg} / \mathrm{L}$. However, the control area has a higher amount of TDS. In the control area, agricultural activity is intensive as well as industrial activities. This may be responsible for the higher values.

\section{Turbidity}

Water turbidity is very important because high turbidity is often associated with a higher level of disease-causing organisms such as bacteria and other parasites (Shittu et al. 2008). The turbidity values of all the water samples analyzed were above the WHO (2006) permissible limit of 5 NTU. This may be due to the presence of a large amount of inorganic particulate matter, suspended

Table 2 Physicochemical property of water samples

\begin{tabular}{llllll}
\hline Samples & $\mathrm{pH}$ & $\mathrm{Tb}(\mathrm{NTU})$ & $\mathrm{EC}(\mu \mathrm{S} / \mathrm{cm})$ & $\mathrm{TDS}(\mathrm{mg} / \mathrm{L})$ & $\mathrm{DO}(\mathrm{mg} / \mathrm{L})$ \\
\hline E-M well & $6.06 \pm 0.20$ & $13 \pm 0.0$ & $202.37 \pm 3.73$ & $121.67 \pm 2.48$ & $3.27 \pm 0.1$ \\
E-M pond & $6.57 \pm 0.12$ & $2271 \pm 0.00$ & $39.27 \pm 0.29$ & $25.00 \pm 2.30$ & $3.5 \pm 0.30$ \\
M-E well & $5.66 \pm 0.02$ & $19 \pm 0.0$ & $757.33 \pm 5.69$ & $450.67 \pm 6.03$ & $3.1 \pm 0.30$ \\
\hline
\end{tabular}

Tb turbidity, C conductivity, TDS total dissolved solids, DO dissolved oxygen, E.M Edege-Mbeki, M.E Mararaban-Edege (control) 
minerals, bacteria, and plankton, as well as dissolved organic and inorganic substances. The high turbidity values obtained, therefore, indicate that the water located in the study area is unhealthy for human use and consumption. Besides, the high turbidity of the water decreases the concentration of oxygen in the water and the photosynthetic activity of plants and algae (Teng et al. 2007).

\section{Dissolved oxygen (DO)}

Dissolved oxygen is one of the most important parameters used to measure water quality and to determine the degree of freshness of a river (Fakayode 2005). It is also used to indicate the level of organic pollution in a water body (Wetzel and Likens 2006). It is important to note that there is a direct relationship between the amount of dissolved oxygen and temperature as well as biological activities (Chapman and Kimstach 1992). The maximum DO level recorded at the mining ponds was $(3.5 \pm$ $0.3 \mathrm{mg} / \mathrm{L}$ ) while $3.1 \pm 0.3 \mathrm{mg} / \mathrm{L}$ was the minimum recorded in Mararaban-Edege. The high value recorded in surface water may be attributed to the open-source of the water and is highly enriched with oxygen from the atmosphere. For all the water samples analyzed, the values were below the $5-\mathrm{mg} / \mathrm{L}$ minimum standard limit
(WHO 2006). These low values of DO might retard the biochemical reactions in all the water samples.

\section{Heavy metals}

Water contamination by heavy metals $(\mathrm{Ni}, \mathrm{Mn}, \mathrm{Pb}, \mathrm{Cd}$, and $\mathrm{Fe}$ ) was evaluated by comparing their concentrations with the guidelines for drinking water and surface water established by the Standard Organisation of Nigeria $(\mathrm{SON})$. The surface and groundwater resource in the study area plays an important role in the supply of water resources for human consumption, agricultural, and mining activity. Standard Organisation of Nigeria (SON) served as the primary guideline against which to evaluate the heavy metal contamination (Table 3).

The result of heavy metals in the study area shows that the level of nickel in all the water samples was above the recommended level by the Nigerian standard (Table 4) except for well water in Edege-Mbeki. This could pose a serious health challenge to the inhabitants of the study area. Research shows that contact with nickel or nickel compounds has adverse effects such as contact dermatitis, lung fibrosis, cardiovascular, and kidney disease as well as cancer of the respiratory tract. Other health effects include nausea, vomiting, cough, giddiness,

Table 3 Nigeria National Quality Standards for drinking water and surface water (Standard Organisation of Nigeria 2007)

\begin{tabular}{|c|c|c|c|c|}
\hline Parameter & Unit & $\begin{array}{l}\text { Maximum } \\
\text { Permitted }\end{array}$ & Health Impact & Note \\
\hline Aluminum (Al) & $\mathrm{mg} / \mathrm{L}$ & 0.2 & Potential Neuro-degenerative disorders & Note 2 \\
\hline Arsenic (As) & $\mathrm{mg} / \mathrm{L}$ & 0.01 & Cancerr & \\
\hline Barium & $\mathrm{mg} / \mathrm{L}$ & 0.7 & Hypertension & \\
\hline Cadmium (Cd) & $\mathrm{mg} / \mathrm{L}$ & 0.003 & Toxic to the kidney & \\
\hline Chloride $(\mathrm{Cl})$ & $\mathrm{mg} / \mathrm{L}$ & 250 & None & \\
\hline Chromium $\left(\mathrm{Cr}^{6+}\right)$ & $\mathrm{mg} / \mathrm{L}$ & 0.05 & Cancer & \\
\hline Conductivity & $\mu \mathrm{S} / \mathrm{cm}$ & 1000 & None & \\
\hline Copper $\left(\mathrm{Cu}^{+2}\right)$ & $\mathrm{mg} / \mathrm{L}$ & 1 & Gastrointestinal disorder, & \\
\hline Cyanide $\left(\mathrm{CN}^{-}\right)$ & $\mathrm{mg} / \mathrm{L}$ & 0.01 & Very toxic to the thyroid and the nervous system & \\
\hline Fluoride ( $\left.\mathrm{F}^{-}\right)$ & $\mathrm{mg} / \mathrm{L}$ & 1.5 & Fluorosis, Skeletal tissue (bones and teeth) morbidity & \\
\hline Hardness (as $\left.\mathrm{CaCO}_{3}\right)$ & $\mathrm{mg} / \mathrm{L}$ & 150 & None & \\
\hline Hydrogen Sulphide $\left(\mathrm{H}_{2} \mathrm{~S}\right)$ & $\mathrm{mg} / \mathrm{L}$ & 0.05 & None & \\
\hline Iron $\left(\mathrm{Fe}^{+2}\right)$ & $\mathrm{mg} / \mathrm{L}$ & 0.3 & None & \\
\hline Lead $(\mathrm{Pb})$ & $\mathrm{mg} / \mathrm{L}$ & 0.01 A & $\begin{array}{l}\text { Cancer, interference with Vitamin D metabolism, affect mental } \\
\text { development in infants, toxic to the central and peripheral nervous systems }\end{array}$ & \\
\hline Magnesium $\left(\mathrm{Mg}^{+2}\right)$ & $\mathrm{mg} / \mathrm{L}$ & 20 & Consumer acceptability & \\
\hline Manganese $\left(\mathrm{Mn}^{+2}\right)$ & $\mathrm{mg} / \mathrm{L}$ & 0.2 & Neurological disorder $U_{N L Y}$ & \\
\hline Mercury $(\mathrm{Hg})$ & $\mathrm{mg} / \mathrm{L}$ & 0.001 & Affects the kidney and central nervous system & \\
\hline Nickel (Ni) & $\mathrm{mg} / \mathrm{L}$ & 0.02 & Possible carcinogenic & \\
\hline Nitrate $\left(\mathrm{NO}_{3}\right)$ & $\mathrm{mg} / \mathrm{L}$ & 50 & $\begin{array}{l}\text { Cyanosis, and asphyxia ("blue-baby syndrome") in infants under } 3 \text { months } \\
\text { syndrome") in infants under } 3 \text { months }\end{array}$ & \\
\hline Nitrite $\left(\mathrm{NO}_{2}\right)$ & $\mathrm{mg} / \mathrm{L}$ & 0.2 & Cyanosis, and asphyxia ("blue-baby syndrome") in infants under 3 months & \\
\hline $\mathrm{pH}$ & - & $6.5-8.5$ & None & \\
\hline Sodium $(\mathrm{Na})$ & $\mathrm{mg} / \mathrm{L}$ & 200 & None & \\
\hline Sulphate $\left(\mathrm{SO}_{4}\right)$ & $\mathrm{mg} / \mathrm{L}$ & 100 & None & \\
\hline Total Dissolved Solids & $\mathrm{mg} / \mathrm{L}$ & 500 & None & \\
\hline Zinc (Zn) & $\mathrm{mg} / \mathrm{L}$ & 3 & None & \\
\hline
\end{tabular}


Table 4 Heavy metal content of Edege-Mbeki and MararabanEdege water samples

\begin{tabular}{llll}
\hline Parameters & E-M well $(\mathrm{mg} / \mathrm{L})$ & E-M pond $(\mathrm{mg} / \mathrm{L})$ & M-E well $(\mathrm{mg} / \mathrm{L})$ \\
\hline Nickel $(\mathrm{Ni})$ & $0.008 \pm 0.01$ & $0.102 \pm 0.001$ & $0.032 \pm 0.05$ \\
Manganese $(\mathrm{Mn})$ & $0.087 \pm 0.026$ & $0.099 \pm 0.085$ & $0.096 \pm 0.086$ \\
Lead $(\mathrm{Pb})$ & $0.324 \pm 0.0 .047$ & $0.358 \pm 0.313$ & $0.122 \pm 0.018$ \\
Cadmium $(\mathrm{Cd})$ & $0.029 \pm 0.002$ & $0.025 \pm 0.001$ & $0.039 \pm 0.002$ \\
Iron (Fe) & $0.839 \pm 0.736$ & $6.99 \pm 6.06$ & $0.608 \pm 0.03$ \\
\hline
\end{tabular}

E.M Edege-Mbeki, M.E Mararaban-Edege (control)

headache, abdominal problems, diarrhea, and visual disturbance (El Safty et al. 2018).

The level of manganese in all the water samples analyzed was below the maximum desirable limit as specified in the national and international standards. This means the people may not suffer from the problem of manganese, because excess manganese can increase bacterial growth, interfere with the ingestion of dietary iron, and cause hypertension in patients older than 40 years (Adewoye et al. 2013).

The most significant of all heavy metals are lead $(\mathrm{Pb})$ owing to its toxicity and abundance in the earth's crust (Gregoriadou et al. 2001). Lead is harmful even in the minutest quantity (Adewoye et al. 2013). Children are more susceptible to $\mathrm{Pb}$ exposure than adults; it has been shown to impair children's physical growth and lowering their intelligence (Agency for Toxic Substance and Disease Registry 2007). Exposure to lead has been associated with attention deficit, hyperactivity disorder, antisocial behavior, an endocrine disorder, and hormonal dysfunction. Furthermore, lead is a known carcinogen and a neurotoxin substance (Bellinger 2008). All the water samples analyzed showed lead $(\mathrm{Pb})$ concentration above the maximum permissible limit as specified by the SON standard, indicating $\mathrm{Pb}$ contamination. The high concentration of $\mathrm{Pb}$ may result in metallic poisoning that manifests in possible human carcinogens (Bakare-Odunola 2005).

Cadmium is a known carcinogen, especially for lung cancer. It also causes kidney, intestinal, and lung damage. Cadmium is associated with behavioral and learning defects, low fetal weight, and skeletal deformation in pregnant animals. Research also suggests that low sperm count and low birth weight are caused by cadmium (EPA 2007). In the study under review, cadmium was above the national and international permissible limit, meaning there was cadmium contamination.

Fe is a necessary element found in nearly all living organisms and is considered at the border between macro and microelements. Iron-containing enzymes and proteins often contain heme-prosthetic groups that participate in many biological oxidations and transport (Chandra et al. 2009). The concentration of iron ranged from a minimum of $0.608 \pm 0.540 \mathrm{mg} /$ $\mathrm{L}$ to a maximum of $6.99 \pm 6.06 \mathrm{mg} / \mathrm{L}$. The iron $(\mathrm{Fe})$ content of all the water samples was found to be below the WHO (2004) maximum permissible limit of $1 \mathrm{mg} / \mathrm{L}$ except for surface water in Edege-Mbeki $(6.99 \pm 6.06)$. Though an important component of human dietary requirement required by hemoglobin, a high concentration of iron is stored in the pancreas, heart, spleen, and the liver. This may end up damaging these vital organs. Furthermore, the presence of excess iron in water affects the taste as well as promotes the growth of iron bacteria that increases the rate of rusting (Chukwu et al. 2008).

From the foregoing, the result of the water quality in Edege-Mbeki mining district was within the permissible limit values concerning the physicochemical parameters. However, the water samples were contaminated with alarming levels of $\mathrm{Ni}, \mathrm{Cd}$, and $\mathrm{Pb}$. Therefore, the water quality is not good, and it is contaminated; hence, appropriate measures need to be put in place to avoid an outbreak of diseases.

The results of the contamination factor (CF), modified contamination degree $(\mathrm{mCd})$, and enrichment factors (EF) of the water samples are shown in Tables 5 and 6.

All the water samples analyzed showed very high contamination $(\mathrm{CF}>6)$ for $\mathrm{Pb}$ and $\mathrm{Cd}$, while the remaining samples showed low to medium contamination. Mining pond water in Edege-Mbeki recorded the highest contamination degree of 11.29 for all the heavy metals analyzed. The well waters of both Edege-Mbeki and Mararaban-Edege recorded moderately low to high values of contamination degree (5.53-8.71).

The enrichment factors (EF) calculated for nickel $(\mathrm{Ni})$ and manganese $(\mathrm{Mn})$ for all the water samples was lower than 2 except for nickel in MararabanEdege, thus highlighting their natural origin in the water samples. However, except Edege-Mbeki surface water (mining pond), the enrichment factor for lead $(\mathrm{Pb})$ and cadmium $(\mathrm{Cd})$ in the water samples was found to be greater than 2 . On the whole, the

Table 5 Contamination factors (CF) and modified contamination degree $(\mathrm{mCd})$ of heavy metals in water samples

\begin{tabular}{lllllllll}
\hline Location/site & Source & \multicolumn{4}{c}{ Contamination factor (CF) } & \multirow{2}{*}{ mCd } \\
\cline { 3 - 7 } & & Well & 0.4 & 0.218 & 32.4 & 9.67 & 0.84 & 8.71 \\
\hline Edege-Mbeki & Mn & $\mathrm{Pb}$ & $\mathrm{Cd}$ & $\mathrm{Fe}$ & \\
& Mining pond & 5.1 & 0.248 & 35.8 & 8.33 & 6.99 & 11.29 \\
$\begin{array}{l}\text { Mararaban-Edege } \\
\text { (control) }\end{array}$ & Well & 1.6 & 0.24 & 12.2 & 13 & 0.61 & 5.53 \\
\hline
\end{tabular}


Table 6 Enrichment factor for water samples using iron (Fe) as a reference element for average

\begin{tabular}{llllll}
\hline Location/site & \multirow{2}{*}{ Source } & \multicolumn{4}{c}{ Enrichment factor (EF) } \\
\cline { 3 - 7 } & & $\mathrm{Ni}$ & $\mathrm{Mn}$ & $\mathrm{Pb}$ & $\mathrm{Cd}$ \\
\hline Edege-Mbeki & Well & 0.477 & 0.259 & 38.62 & 11.52 \\
& Mining ponds & 0.729 & 0.035 & 5.12 & 1.19 \\
Mararaban-Edege (control) & Well & 2.63 & 0.39 & 20.07 & 21.38 \\
\hline
\end{tabular}

presence of lead $(\mathrm{Pb})$ and cadmium $(\mathrm{Cd})$ in the water samples of the study area may be due to anthropogenic origin and artisanal tantalite/columbite mining probably.

\section{Conclusion}

The physicochemical properties of water samples were generally within the national and international acceptable limits. On the other hand, groundwaters of all the studied villages, as well as surface water of Edege-Mbeki, were contaminated with $\mathrm{Ni}, \mathrm{Cd}, \mathrm{Fe}$, and $\mathrm{Pb}$. This implies that all the water sources within the mining district of Edege-Mbeki (Nasarawa Local Government Area of Nasarawa state) may not be fit for drinking purposes.

\section{Recommendations}

The authors recommend the regular monitoring and evaluation of water and sediment samples in EdegeMbeki all year round. Furthermore, for the biodiversity and endangered species to be protected, spatial assessment of water and sediment samples in Edege-Mbeki mining district is recommended.

\section{Abbreviations}

AAS: Atomic absorption spectrometer; COLTAN: Columbite/tantalite; SON: Standard Organisation of Nigeria; WHO: World Health Organization

\section{Acknowledgements}

The authors wish to thank the Multi-User Science Research Laboratory (MUSRL) of the Department of Chemistry Ahmadu Bello University Zaria and the National Research Institute for Chemical Technology (NARICT) Zaria for the Laboratory and AAS Analysis.

\section{Authors' contributions}

The design and experiments of this research for the in situ measurement, sample collection, preservation, and analysis of heavy metals were performed by MEI. NAA and PDE supervised and guided the work while EAK provided access to his laboratory and helped with digestion. All authors read and approved the final manuscript.

\section{Funding}

The cost associated with the collection, analysis, and interpretation of data in this manuscript was the responsibility of the corresponding author.

\section{Availability of data and materials}

General data repository and workflow management/versioning connect to other services; free Open Science Framework.

\section{Ethics approval and consent to participate}

This study does not involve the use of human, animal data, and tissue or human participants.
Consent for publication

Not applicable

\section{Competing interests}

The author declares that they have no competing interests.

\section{Author details}

${ }^{1}$ Renaissance Environmental Limited, No 12 Cape Town Street Wuse District Zone 4, Abuja, Nigeria. ${ }^{2}$ Department of Chemistry, Ahmadu Bello University Zaria, PMB 1045, Zaria, Kaduna, Nigeria. ${ }^{3}$ National Research Institute for Chemical Technology (NARICT), Bassawa Road, Zaria, Kaduna, Nigeria.

Received: 8 October 2019 Accepted: 19 November 2019

Published online: 09 December 2019

\section{References}

Abrahim GMS, Parker RJ (2008) Assessment of heavy metal enrichment factors and the degree of contamination in marine sediments from Tamaki Estuary, Auckland, New Zealand. Environ Monit Assess::227-238

Adejumoke I, Babatunde A, Abimbola O, Tabitha A, Adewumi D, Toyin O (2018) Water pollution effects, prevention, and climatic impact. Water challenges of an urbanizing world. https://doi.org/10.5772/intechopen.72018

Adewoye S, Adewoye A, Opasola O, Elegbede J (2013) Physicochemical parameters and heavy metal analyses of water samples from hand dug wells in Gambari, Ogbomoso, Oyo State. IOSR Journal of Environmental Science, Toxicology and Food Technology 5:1

Agency for Toxic Substances and Disease Registry (ATSDR) 2017. Lead Toxicity What Are Possible Health Effects from Lead Exposure? Available: https:// www.atsdr.cdc.gov/csem/csem.asp?csem $=34 \& p o=10$.

Akintola JO (1986) Rain distribution in Nigeria 1892-1983. Impact publishers Nigeria limited, Ibadan, Nigeria, p 371

APHA (2005) Standard methods for the examination of water and wastewater. 20th American Public Health Association, Washington DC, p 1-161

Ata S, Farid M, Soroush M (2009) Heavy metal contamination and distribution in the Shiraz industrial complex zone soil, South Shiraz, Iran. World Appl Sci J 6(3):413-425

Bakare-Odunola MT (2005) Determination of some metallic impurities present in soft drinks marketed in Nigeria. The Nig J Pharm 4(1):51-54

Bellinger D (2008) Very low lead exposures and children's neurodevelopment. Curr Opin Pediatr 20(2):172-177

Bhupander K, Sanjay K, Meenu M, Prakash D, Singh SK, Sharma CS, Mukherjee DP (2011) An assessment of heavy metals in sediments from two tributaries of lower stretch of Hugli estuary in West Bengal. Archives of Applied Science Research 3(4):139-146

Boamponsem LK, Adam Jl, Dampare SB, Owusu-Ansah E, Addae G (2010) Heavy metals level in streams of Tarkwa gold mining area of Ghana. J Chem Pharm Res 2(3):504-527

Chapman, D., Kimstach, V., (1992) The selection of water quality variable: In water quality assessments (Chapman, D. Ed.) Chapman and Hall Ltd., London pp. 51-119

Chukwu O, Mustapha HI, Abdul-Gafar HB (2008) The effect of Minna abattoir waste on surface water quality. I Environ Res J 2(6):334-338

Corkhill CL, Vaughan DJ. (2009) Arsenopyrite Oxidation - A Review. Applied Geochemistry Article in Press. https://doi.org/10.1016/j.apgeochem.2009.09. 008.

Eisler R (2004) Arsenic hazards to humans, plants and animals from gold mining. Rev Environ Contam Toxicol 180:133-165

El Safty A, Samir A, Mekkawy M, Fouad M (2018) Genotoxic effects due to exposure to chromium and nickel among electroplating workers. Int J Toxicol 37(3):234-240

EPA (2007) Environmental Protection Agency, Safe Drinking Water Act. EPA 816F-03 016.

Fakayode SO (2005) Impart of industrial effluent on water quality of the receiving Alero River in Ibadan. Ajeam-Ragee 10:1-13

Franco-Hernández M, Vásquez-Murrieta M, Patiño-Siciliano A, Dendooven L (2010) Heavy metals concentration in plants growing on mine tailings in Central Mexico. Bioresour Technol 101(11):3864-3869. https://doi.org/10. 1016/j.biortech.2010.01.013

Gregoriadou, A., Delidou, K., Dermosonoglou, D., Tsoumparis, P., Edipidi, C., and Katsougiannopoulos, B. (2001) Heavy metals in drinking water in Thessaloniki 
Area, Greece. Proceedings of the 7th International Conference on Environmental Science and Technology, Aristotle University, Ermoupolis

Hernadez L, Probst JL, Ulrich E (2003) Heavy metal distribution in some Frech forest soil, evidence for atmospheric contamination. Sci Total Environ 312: 195-219

Khan A, Bhat U (2011) Heavy metals: an ambiguous category of inorganic contaminants, nutrients and toxins. Res J Environ Sci 5(8):682-690. https:// doi.org/10.3923/rjes.2011.682.690

Masindi V, Muedi K (2018) Environmental contamination by heavy metals. Heavy Metals. https://doi.org/10.5772/intechopen.76082

Mishra V, Kim K, Samaddar P, Kumar S, Aggarwal M, Chacko K (2017) Review on metallic components released due to the use of electronic cigarettes. Environmental Engineering Research 22(2):131-140

Okegye J, Gajere J (2015) Assessment of heavy metal contamination in surface and ground water resources around Udege Mbeki mining district, NorthCentral Nigeria. Journal Of Geology \& Geosciences 04(03). https://doi.org/10 4172/2329-6755.1000203

Ologundudu F (2019) Assessment of heavy metal pollution in a gold mining site in Southwestern Nigeria. Biomedical Journal of Scientific \& Technical Research 12(4). https://doi.org/10.26717/bjstr.2019.12.002276

Olorundare O, Ipinmoroti K, Popoola A, Ayenimo J (2011) Anthropogenic influence on selected heavy metal contamination of urban soils of Akure City, Nigeria. Soil Sediment Contam Int J 20(5):509-524

Ong MC, Menier DZ, Shazili NAM, Kamaruzzaman BY (2012) Geochemical characteristics of heavy metals concentration in sediments of Quiberon Bay Waters, South Brittany, France. Orient J Chem 29(1):39-45

Orebiyi EO, Awomeso JA, Idowu OA, Martins O, Oguntoke O, Taiwo AM (2010) Assessment of pollution hazards of shallow well water in Abeokuta and environs, Southwest, Nigeria. Am J Environ Sci 6(1):50-56

Osinbajo, A. (2012) Destructive effect of sunlight on bacteria in oral rehydration solution contaminated with sewage. Lancet Dec., pp. 1259-1258

Popoola OE, Abiodun AA, Oyelola OT, Ofodile LN (2011) Heavy metals in topsoil and effluent from an electronic waste dumpsite in Lagos state. J. Environ. Issues, 1(1): pp 57-63. Available online @www.jenvscs.com

Said K, Shuhaimi M, Ahmad A (2012) The evaluation of water quality and metal concentrations of Titiwangsa Lake, Selangor, Peninsular Malaysia. Pak J Biol Sci 15(10):459-468. https://doi.org/10.3923/pjbs.2012.459.468

Shittu OB, Olaitan JO, Amusa TS (2008) Physicochemical and bacteriological analysis of water used for drinking and swimming purpose. Afr J Biochem Res 11:285-290

Standards Organisation of Nigeria (2007) Nigerian standard for drinking water quality, Abuja, Nigeria. Water System Council (2007) "Wellcare Publications" Retrieved from www.wellcarehotline.org

Teng W, Guoxiang W, Qiang L (2007) Effects of water turbidity on the photosynthetic characteristics of Myriophyllum spicatum L. Asian J Plant Sci 6(5):773-780. https://doi.org/10.3923/ajps.2007.773.780

Wei W, Ma R, Sun Z, Zhou A, Bu J, Long X, Liu Y (2018) Effects of mining activities on the release of heavy metals (HMs) in a typical mountain headwater region, the Qinghai Tibet Plateau in China. Int J Environ Res Public Health 15(9):1987

Wetzel RG, Likens GE (2006) Limnological analysis. Third edition. Springer-Verlag, New York, p 391

WHO (2004) Guideline for drinking-water quality, health criteria and supporting information, World Health Organisation (WHO), $2^{\text {nd }}$ edition, Volume 2, Geneva

WHO (2006) Guidelines for drinking-water quality (electronic resource). Incorporating first addendum. 3rd edn, volume 1. Recommendations. World Health Organization, Geneva

\section{Publisher's Note}

Springer Nature remains neutral with regard to jurisdictional claims in published maps and institutional affiliations.

\section{Submit your manuscript to a SpringerOpen ${ }^{\circ}$ journal and benefit from:}

- Convenient online submission

- Rigorous peer review

- Open access: articles freely available online

- High visibility within the field

- Retaining the copyright to your article

Submit your next manuscript at $\boldsymbol{\nabla}$ springeropen.com 